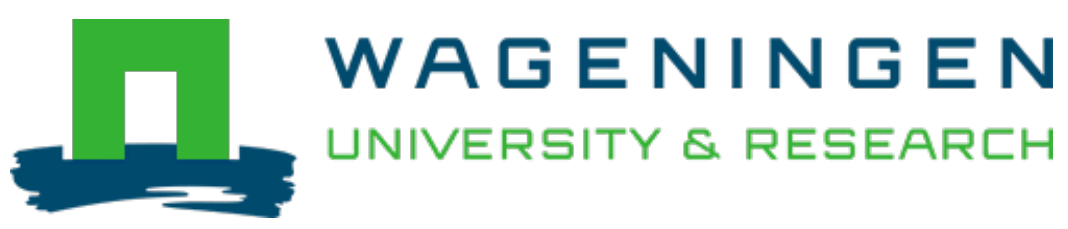

\author{
Genetic and Environmental Impact on Iron, Zinc, and Phytate in Food Sorghum \\ Grown in Benin \\ Journal of Agricultural and Food Chemistry \\ Kayodé, A.P.P.; Linnemann, A.R.; Hounhouigan, J.D.; Nout, M.J.R.; Boekel, M.A.J.S. \\ https://doi.org/10.1021/jf0521404
}

This publication is made publicly available in the institutional repository of Wageningen University and Research, under the terms of article $25 \mathrm{fa}$ of the Dutch Copyright Act, also known as the Amendment Taverne. This has been done with explicit consent by the author.

Article 25 fa states that the author of a short scientific work funded either wholly or partially by Dutch public funds is entitled to make that work publicly available for no consideration following a reasonable period of time after the work was first published, provided that clear reference is made to the source of the first publication of the work.

This publication is distributed under The Association of Universities in the Netherlands (VSNU) 'Article $25 \mathrm{fa}$ implementation' project. In this project research outputs of researchers employed by Dutch Universities that comply with the legal requirements of Article $25 \mathrm{fa}$ of the Dutch Copyright Act are distributed online and free of cost or other barriers in institutional repositories. Research outputs are distributed six months after their first online publication in the original published version and with proper attribution to the source of the original publication.

You are permitted to download and use the publication for personal purposes. All rights remain with the author(s) and / or copyright owner(s) of this work. Any use of the publication or parts of it other than authorised under article $25 \mathrm{fa}$ of the Dutch Copyright act is prohibited. Wageningen University \& Research and the author(s) of this publication shall not be held responsible or liable for any damages resulting from your (re)use of this publication.

For questions regarding the public availability of this publication please contact openscience.library@wur.nl 


\title{
Genetic and Environmental Impact on Iron, Zinc, and Phytate in Food Sorghum Grown in Benin
}

\author{
A. P. Polycarpe Kayodé,$^{\dagger}$ Anita R. Linnemann,${ }^{\S}$ Joseph D. Hounhouigan,${ }^{\dagger}$ \\ Martinus J. R. Nout, ${ }^{*} \S$ and Martinus A. J. S. van BoeKel ${ }^{\S}$ \\ Faculté des Sciences Agronomiques, Université d'Abomey-Calavi, 01 B.P. 526, Cotonou, Bénin, and \\ Department of Agrotechnology and Food Sciences, Wageningen University, P.O. Box 8129, \\ 6700 EV Wageningen, The Netherlands
}

\begin{abstract}
Seventy-six farmers' varieties of sorghum from Benin were distinguished by amplified fragment length polymorphism (AFLP) and clustered into 45 distinct genotypes. The genotype clusters were evaluated for their $\mathrm{Fe}, \mathrm{Zn}$, and phytate concentrations to assess the impact of genetic and environmental effects on the composition of the grains and to identify farmers' varieties with high potential $\mathrm{Fe}$ and $\mathrm{Zn}$ availability. The $\mathrm{Fe}$ concentration of the grains ranged from 30 to $113 \mathrm{mg} / \mathrm{kg}$ with an average of 58 $\mathrm{mg} / \mathrm{kg}$. The Zn concentration ranged from 11 to $44 \mathrm{mg} / \mathrm{kg}$ with an average of $25 \mathrm{mg} / \mathrm{kg}$. The phytate concentration of the grain ranged from 0.4 to $3.5 \%$ with a mean of $1.2 \%$. The grain-Fe and grain-Zn did not show consistent linkage to genetic variation, but varied significantly across field locations, suggesting a predominant environmental impact. The phytate concentration of the grains appeared to be environmentally as well as genetically determined. No varieties provide adequate $\mathrm{Zn}$ to meet nutritional requirements of sorghum consumers. The most promising varieties for Fe supply were tokogbessenou, mahi swan, biodahu, saï maï, mare dobi, sakarabokuru, and chabicouma, as they showed a [phytate]/[Fe] ratio of $<14$, which is the critical value above which Fe availability is strongly impaired. These varieties could therefore be recommended for the preparation of food products such as dibou, in which processing methods have only a slight diminishing effect on phytate levels. Further research is needed to test these varieties for the stability of [phytate]/[Fe] molar ratio across various environmental conditions.
\end{abstract}

KEYWORDS: AFLP; genotype; molar ratio

\section{INTRODUCTION}

Iron $(\mathrm{Fe})$ and zinc $(\mathrm{Zn})$ deficiencies constitute a major public health problem in many African countries. They mostly affect infants and pregnant women and may have serious consequences. Chronic micronutrient deficiencies, particularly of Fe, Zn, and vitamin A, cause child mortality, impaired mental and physical development, and decreased work output and contribute to morbidity from infections $(1-3)$.

In semiarid tropics worldwide, sorghum [Sorghum bicolor (L.) Moench] is cultivated by farmers on a subsistence level for human consumption (4). The crop is processed into different local foods such as porridges and beverages, for adults and infants (5). The average yearly sorghum consumption amounts to $115 \mathrm{~kg}$ per capita in northern Benin (6) and $200 \mathrm{~kg}$ per capita in Burkina-Faso (7). Meat consumption is low in these regions as in most developing countries, and therefore cereals and vegetables are the main dietary sources of macro- and micronutrients (8). However, the minerals content of cereals such as

* Corresponding author (fax +31 317 484978; e-mail rob.nout@wur.nl).

† Université d'Abomey-Calavi.

$\S$ Wageningen University. sorghum is low, and their bioavailability is restricted by antinutritional factors such as phytate forming insoluble complexes with essential minerals such as calcium, iron, and zinc at physiological $\mathrm{pH}$ levels (9). Phytate may be partly responsible for the widespread mineral deficiencies observed in populations that subsist largely on sorghum and other cereals (10). The chelating properties of phytate depend on the levels of $\mathrm{Fe}, \mathrm{Zn}$, and phytate. Hence, the molar ratio of phytate to $\mathrm{Fe}$ or $\mathrm{Zn}$ was suggested as an index to estimate the availability of $\mathrm{Fe}$ and $\mathrm{Zn}$ in foods $(11,12)$. A [phytate]/[Fe] molar ratio of $>10-14$ was reported to strongly impair Fe availability in rats fed wheatbased diets (11). Values of 10-15 for the [phytate]/[Zn] molar ratio are considered to be the critical values above which $\mathrm{Zn}$ availability decreases in humans $(13,14)$. In the present study, we used the [phytate]/[Fe] and [phytate]/[Zn] molar ratios as indices for potential $\mathrm{Fe}$ and $\mathrm{Zn}$ availability from the local sorghum varieties.

Frossard et al. (15) postulated that improvement of bioavailability of $\mathrm{Fe}, \mathrm{Zn}$, and $\mathrm{Ca}$ in the edible part of staple crops, such as cereals, could be achieved by increasing the total Fe, Zn, and $\mathrm{Ca}$ levels combined with increasing the concentration of compounds that promote their uptake and/or by decreasing the 
concentration of compounds such as phytate or phenolic compounds, which inhibit their absorption. This could be supported by selection of varieties (for example, within local germplasm) containing enhanced levels of $\mathrm{Fe}$ and $\mathrm{Zn}$ concentration or by breeding for varieties with lower [phytate]/[Fe] and [phytate]/[Zn] ratios. Breeders need existing information on the genetic variation for a given trait as well as the determinants (for instance, genetic and environmental factors) in a collection of germplasm to justify selection for that trait (3). Genetic as well as environmental factors can significantly affect $\mathrm{Fe}$ and $\mathrm{Zn}$ levels in cereal grains as was shown in maize and wheat $(16,17)$. There are limited data available on $\mathrm{Fe}, \mathrm{Zn}$, and phytate contents of sorghum grains.

Local sorghum landraces possess desirable characteristics; that is, they are well adapted to harsh environmental conditions, offer good food quality, are highly preferred by consumers, and thus play a significant role in local economies $(18-21)$. This local germplasm may also have specific advantages in terms of mineral concentration and availability. A recent survey in northern Benin revealed the existence of a large number of farmers' varieties of sorghum that have been selected by farmers over the years and that fulfill relevant user criteria (5). Identification and promotion of local germplasm with high mineral availability can contribute to the improvement of the micronutrient status of the consumers, because they may have a relatively high chance of adoption by the users compared to newly bred varieties from elsewhere.

For the present study we collected sorghum samples $(n=$ 76) from farmers' fields in northern Benin, grown under natural conditions and traditional farming systems to take the variability of these factors into account. Amplified fragment length polymorphism (AFLP; 22), a genome fingerprinting technique, was applied to cluster farmers' varieties according to their genomic similarity. Clusters were evaluated for $\mathrm{Fe}, \mathrm{Zn}$, and phytate concentrations in relation to their growing environment and food quality. The farmers' varieties including environmental conditions with potential for adequate $\mathrm{Fe}$ and $\mathrm{Zn}$ supply to the consumers were identified.

\section{MATERIALS AND METHODS}

Plant Materials. Grains of 76 farmers' varieties of sorghum were provided by farmers in three communities in northern Benin, that is Banikoara (latitude ${ }^{\circ} \mathrm{N}, 11^{\circ} 15^{\prime}$; longitude ${ }^{\circ} \mathrm{E}, 2^{\circ} 23^{\prime}$ ); Toucountouna (latitude ${ }^{\circ} \mathrm{N}, 10^{\circ} 27^{\prime}$; longitude ${ }^{\circ} \mathrm{E}, 1^{\circ} 22^{\prime}$ ); and Djougou (latitude ${ }^{\circ} \mathrm{N}$, $9^{\circ} 43^{\prime}$; longitude $\left.{ }^{\circ} \mathrm{E}, 1^{\circ} 41^{\prime}\right)$. The accessions studied represent farmers' varieties that are the product of development and/or maintainance of seeds by farmers. These farmers' varieties were previously surveyed by Kayodé et al. (23) and described as diverse in terms of their agromorphological traits and food properties. Of the varieties analyzed, $52 \%$ mature late in the season, $15 \%$ mature at an intermediate date, and $33 \%$ mature early. Most have long stems (87\%), loose panicles (79\%), large seeds $(49 \%)$, and a pink or red seed color $(52 \%)$. In addition, most of them are susceptible to drought $(54 \%)$ and attacks by striga (79\%), insects (99\%), and birds $(77 \%)$. The quality of the seeds for preparing porridges is high for $52-54 \%$ of the varieties, whereas $26 \%$ of the varieties are regarded as having a high quality for beverage making, according to the interviewed farmers and food processors.

The collected seeds were from crops grown in 2002 under the natural season of the Guinea Savannah climate of West Africa. The annual rainfall in the region varies from 1000 to $1300 \mathrm{~mm}$, and the average yearly temperature is $26.5^{\circ} \mathrm{C}(24)$. The soil is a tropical ferruginous type (25). After harvesting, the grains were dried to a moisture content of $11-13 \%(\mathrm{w} / \mathrm{w})$. Parts of the seed samples were germinated to produce biomass for DNA extraction. The remainder was ground into flour using a Retsch mill fitted with a $0.5 \mathrm{~mm}$ screen and stored at $-20{ }^{\circ} \mathrm{C}$ until analysis.
DNA Extraction and AFLP Protocol. DNA extraction and the AFLP protocol were performed as reported earlier by Kayodé et al. (23). A small piece $\left(1 \mathrm{~cm}^{2}\right)$ of freeze-dried leaf tissue was ground with four glass pearls in a Retsch shaking mill, followed by DNA extraction according to the method of Fulton et al. (26). The AFLP method (22) was performed as described by Myburg et al. (27), with separation and detection on a LiCOR automated sequencer. Approximately 80 EcoRI/MseI primer combinations were tested on four samples. Suitable combinations were selected on the basis of the number of unambiguously scorable polymorphic bands. Finally, two primer combinations were selected for analysis: EcoRI-AAC/MseI-CCC and EcoR1-ACA/ MseI-CTG.

Iron and Zinc Determination. Approximately $0.4 \mathrm{~g}$ of sorghum flour was digested using hydrofluoric acid $(40 \%)$ and concentrated nitric acid $(65 \%$ w/w). Next, the concentrations of Fe and $\mathrm{Zn}$ were analyzed by using an inductively coupled plasma optical emission spectrometer (ICP-OES) (Elan 6000, Perkin-Elmer, Norwalk, CT) (28). Analyses were performed in duplicate.

Phytate Determination. Approximately $10 \mathrm{mg}$ of sorghum flour was extracted with $1 \mathrm{~mL}$ of $0.5 \mathrm{~N} \mathrm{HCl}$ containing $50 \mathrm{mg} / \mathrm{L}$ cis-aconitate (internal standard). The mixture was boiled in a water bath at $100{ }^{\circ} \mathrm{C}$ for $15 \mathrm{~min}$ and then centrifuged at $14000 \mathrm{~g}$ for $10 \mathrm{~min}$. The supernatant was diluted 5 times in Millipore water and analyzed using HPLC (Dionex DX300, ICS2500 system, detector range of $10 \mu \mathrm{S}$ ) using the column AS11 (ATC column plus precolumn). Detection was with suppressed conductivity, and the suppression was done with water at the flow rate of $5 \mathrm{~mL} / \mathrm{min}$. The eluent and the elution times used were as follows: $0-5 \mathrm{~min}, 5 \mathrm{mM} \mathrm{NaOH}$; 5-15 min, 5-100 $\mathrm{mM} \mathrm{NaOH}$; 15-20 min, $500 \mathrm{mM} \mathrm{NaOH}$; and 20-35 min, $5 \mathrm{mM} \mathrm{NaOH}$. A standard solution was prepared in Millipore water, containing $5.0 \mathrm{mg} / \mathrm{L} \mathrm{NaNO}_{3}$ (Merck p.a.), $5.0 \mathrm{mg} / \mathrm{L} \mathrm{Na}_{2} \mathrm{SO}_{4}$ (Merck p.a.), $5.0 \mathrm{mg} / \mathrm{L}$ oxalic acid• $2 \mathrm{H}_{2} \mathrm{O}$ (Merck p.a.), $10.0 \mathrm{mg} / \mathrm{L} \mathrm{Na} \mathrm{HPO}_{4} \cdot 2 \mathrm{H}_{2} \mathrm{O}$ (Merck 6346 p.a.), 10 $\mathrm{mg} / \mathrm{L}$ citric acid $\cdot \mathrm{H}_{2} \mathrm{O}$ (Merck K23524044 719 p.a.), $5.0 \mathrm{mg} / \mathrm{L}$ cisaconitate (Aldrich 27194-2), and $10 \mathrm{mg} / \mathrm{L}$ IP6 $\cdot \mathrm{Na}_{12}$ (Sigma P3168 lot 102K0053). Analyses were performed in triplicate.

1000 Kernel Weight (kw) Measurement. The $1000 \mathrm{kw}$ was determined by weighing 100 grains of each sample on a 1/10000 precision balance and multiplying the obtained value by 10 . The weight was expressed on a dry matter basis. Measurements were performed in duplicate.

Statistical Analysis. The data were analyzed using the statistical program SPSS 11.0. The one-way ANOVA model was used to compare means between groups by applying the LSD test. For the genetic data, the presence (1) or absence (0) of each polymorphic AFLP band was scored for all genotypes. The genetic similarity $\left(\mathrm{GS}_{i j}\right)$ was calculated according to method of Nei and Li (29): $\mathrm{GS}_{i j}=2 N_{i j} /\left(N_{i}+N_{j}\right) . N_{i j}$ is the number of bands present in genotypes $i$ and $j, N_{i}$ is the number of bands present in genotype $i$, and $N_{j}$ is the number of bands present in genotype $j$. Tests for correlations between genetic variation and $\mathrm{Fe}$, $\mathrm{Zn}$, or phytate were performed using AMOVA 1.55 (30).

\section{RESULTS AND DISCUSSION}

Genetic Identification of Farmers' Varieties. The AFLP technique used in the present study has been reported as a powerful technique in the identification of many other crop species $(31-33)$. On the basis of the presence or absence of the amplified fragments for each farmers' variety, all germplasm was identified by applying the genetic similarity index (GS). Farmers' varieties with a genetic similarity of $>0.90$ are considered to be related, whereas those with GS $<0.90$ are regarded as distinct (34). The AFLP analysis revealed the genetic similarity of some varieties that were considered to be distinct by farmers (Table 1). Within the 76 samples analyzed, we grouped 42 farmers' varieties into 11 similarity clusters (Table 1). The remaining 34 farmers' varieties were distinct as revealed by AFLP. Within the clusters, the GS averaged 0.92 and varied from 0.90 between the farmers' varieties yacuba and fari to 0.98 between talemoula and toholamoula. Some farmers' varieties 
Table 1. Fe, Zn, and Phytate (IP6) Contents and 1000 Kernel Weight (kw) of 45 Sorghum Genotype Clusters from Bénin

\begin{tabular}{|c|c|c|c|c|c|}
\hline genotype & farmers' varieties included & $\mathrm{Fe}(\mathrm{mg} / \mathrm{kg})$ & $\mathrm{Zn}(\mathrm{mg} / \mathrm{kg})$ & IP6 (\%) & $1000 \mathrm{kw}(\mathrm{g})$ \\
\hline 1 & $\begin{array}{l}\text { mahi swan, dobi monri, bio dahou, } \\
\text { saï maï, yinan a, chamwoka a, } \\
\text { chamwoka c, koussoubakou } \\
\text { sinswan bodehem, tamabano, } \\
\text { mare dobi a }\end{array}$ & $56.3 \pm 9.5[44-77]^{a}$ & $24.9 \pm 3.0[21-31]$ & $0.92 \pm 0.32[0.6-1.45]$ & $28.7 \pm 5.5[23.2-40.1]$ \\
\hline 2 & $\begin{array}{l}\text { dobi konouyirou, boussoukari, fari, } \\
\text { yacouba, baniyani, } \\
\text { yabakanoba }\end{array}$ & $58.7 \pm 12.0[40-73]$ & $27.2 \pm 3.5[22-32]$ & $1.01 \pm 0.37[0.49-1.32]$ & $27.2 \pm 3.1[23.2-31.4$ \\
\hline 3 & $\begin{array}{l}\text { talemoula a, talemoula b, } \\
\text { toholahamoula, agbaneri, } \\
\text { somba hanni }\end{array}$ & $47.8 \pm 6.3[38-53]$ & $27.4 \pm 5.6[21-33]$ & $1.56 \pm 0.39[1.02-2.01]$ & $35.8 \pm 3.3[31.9-39.3]$ \\
\hline 4 & chassissoya, soniya a, kaka, doniyoka & $60.3 \pm 18.6[33-74]$ & $23.0 \pm 7.0[19-34]$ & $0.96 \pm 0.56[0.44-1.72]$ & $26.9 \pm 4.1[23.1-31.2]$ \\
\hline 5 & natisoya $a$, natisoya $b$, tinoukpati & $39.3 \pm 1.5[38-41]$ & $23.0 \pm 5.3[19-29]$ & $1.18 \pm 0.19[0.98-1.35]$ & $31.0 \pm 1.3[30.1-32]$ \\
\hline 6 & sakarabokuru b, dobi gnon faï, bonyinm & $56.3 \pm 19.6[44-79]$ & $31.7 \pm 4.7[28-37]$ & $0.86 \pm 02[0.63-1.02]$ & $29.1 \pm 6.4[25.1-36.6]$ \\
\hline 7 & hanni kpare, zomora, zogua b & $59.0 \pm 12.5[46-71]$ & $20.3 \pm 3.1[17-23]$ & $1.34 \pm 0.37[1.09-1.77]$ & $25.3 \pm 3.5[21.7-28.7]$ \\
\hline 8 & tokogbessenou $b$, mare dobi $b$ & $61.5 \pm 24.7[44-79]$ & $20.0 \pm 1.4[19-21]$ & $0.83 \pm 0.12[0.75-0.92]$ & $n d^{b}$ \\
\hline 9 & soniya b, fissouka & $63.5 \pm 16.3[52-75]$ & $31.5 \pm 3.5[29-34]$ & $1.28 \pm 0.13[1.19-1.37]$ & $36.5 \pm 1.4[36-37]$ \\
\hline 10 & kouwekifounan, koumborosoya & $66.5 \pm 9.2[60-73]$ & $21.3 \pm 0.0[21-21.5]$ & $1.65 \pm 0.12[1.56-1.74]$ & $32.4 \pm 1.3[31.5-33.4$ \\
\hline 11 & kpri hanni, zomora & $68.0 \pm 18.4[55-81]$ & $28.5 \pm 6.4[24-33]$ & $2.27 \pm 0.13[1.48-3.07]$ & $26.0 \pm 6.1[21.6-30.3]$ \\
\hline 12 & gbango & $42.5[41-44]$ & $26.0[24-28]$ & $1.03 \pm 0.03$ & $23.6[23-24]$ \\
\hline 13 & sakarabokuru a & $64.1[60-68]$ & $21.4[21-21.8]$ & $0.72 \pm 0.12$ & $37[37-37]$ \\
\hline 14 & yerekou & $45.0[44-46]$ & $23.0[23-23]$ & $0.92 \pm 0.18$ & $34.0[33.5-34.6]$ \\
\hline 15 & kobatia binyirou & $92.5[84-101]$ & $29.0[26-32]$ & $0.97 \pm 0.06$ & $20.5[20-21]$ \\
\hline 16 & tokogbessenou a & $68.0[49-87]$ & $20.5[20-21]$ & $0.75 \pm 0.21$ & $39.0[39-39]$ \\
\hline 17 & yibere kanyinse & $51.0[48-54]$ & $23.5[23-24]$ & $0.86 \pm 0.31$ & $39.5[39-40]$ \\
\hline 18 & fara bonbo & $46.0[46-46]$ & $14.0[11-17]$ & $0.58 \pm 0.24$ & $33.0[32-34]$ \\
\hline 19 & gourouma dobi & 99.0 [96-102] & 26.0 [24-28] & $0.65 \pm 0.07$ & $27.0[27-27]$ \\
\hline 20 & yinan $b$ & $47.0[44-50]$ & $26.0[26-26]$ & $0.67 \pm 0.21$ & nd \\
\hline 21 & chamwoka b & nd & nd & $0.87 \pm 0.28$ & nd \\
\hline 22 & chabikouman & $40.5[40-41]$ & 19.0 [18-20] & $0.47 \pm 0.07$ & $42.0[41-43]$ \\
\hline 23 & yowinka a & $48.0[46-50]$ & 18.0 [17-19] & $0.92 \pm 0.09$ & 28.1 [27.7-28.5] \\
\hline 24 & yowinka b & $77.0[75-79]$ & 24.0 [22-26] & $0.84 \pm 0.18$ & nd \\
\hline 25 & sotakaman a & $55.5[51-60]$ & $25.5[25-26]$ & $0.45 \pm 0.17$ & 31.6 [31.32] \\
\hline 26 & sotakaman b & $42.5[41-44]$ & 19.5 [19-20] & $1.28 \pm 0.18$ & nd \\
\hline 27 & mousseman & $56.5[56-57]$ & $16.5[16-17]$ & $1.40 \pm 0.16$ & 25.1 [25-25.2] \\
\hline 28 & agbanni & $47.5[47-48]$ & 24.5 [23-26] & $1.35 \pm 0.38$ & $52.0[51-53]$ \\
\hline 29 & kassassahan & 68.5 [68-69] & 18.5 [17-20] & $1.11 \pm 0.11$ & 29.0 [28-30] \\
\hline 30 & zopira & $63.0[56-71]$ & 24.0 [21-26] & $1.17 \pm 0.15$ & 31.5 [31-32] \\
\hline 31 & semoutche & $53.5[53-54]$ & 37.5 [36-39] & $1.57 \pm 0.02$ & 32.5 [32-33] \\
\hline 32 & gaouri oleri & $40.0[39-41]$ & $38.0[32-44]$ & $1.30 \pm 0.06$ & $40.5[40-41]$ \\
\hline 33 & zogua a & $63.0[60-66]$ & 26.0 [25-27] & $1.20 \pm 0.24$ & $48.5[48-49]$ \\
\hline 34 & moussi & $63.0[61-65]$ & $28.5[26-31]$ & $0.95 \pm 0.19$ & $25.0[24-26]$ \\
\hline 35 & sobaki & $86.0[85-87]$ & $16.5[16-17]$ & $1.62 \pm 0.20$ & $6.5[5-8]$ \\
\hline 36 & mahi a & $38.5[37-40]$ & 20.0 [20-20] & $1.14 \pm 0.09$ & 36.5 [36-37] \\
\hline 37 & mahi b & 79.5 [77-82] & 20.5 [20-21] & $1.68 \pm 0.21$ & 39.5 [39-40] \\
\hline 38 & yabakawerou & $67.0[61-73]$ & $31.0[31-31]$ & $1.45 \pm 0.08$ & nd \\
\hline 39 & gantim & 74.5 [67-82] & $33.0[33-33]$ & $1.15 \pm 0.10$ & nd \\
\hline 40 & sopoya & 31.5 [30-33] & $15.5[14-17]$ & $2.06 \pm 0.37$ & 25.5 [25-26] \\
\hline 41 & sodaya & $72.0[70-74]$ & 28.0 [27-29] & $3.53 \pm 0.41$ & 34.5 [34-35] \\
\hline 42 & saga pica & $55.5[52-59]$ & 23.5 [23-24] & $1.76 \pm 0.19$ & 23.0 [22-22] \\
\hline 43 & hannitchre & $40.0[39-41]$ & 18.5 [17-20] & $2.22 \pm 0.12$ & $36.5[36-37]$ \\
\hline 44 & koussoubakou & 38.6 [37-40] & 26.5 [26-27] & $1.59 \pm 0.28$ & 31.5 [31-32] \\
\hline \multirow[t]{3}{*}{45} & yebode & $94.0[75-113]$ & $34.0[28-40]$ & $1.62 \pm 0.40$ & nd \\
\hline & average & 58.8 & 24.4 & 1.2 & 31.7 \\
\hline & $\mathrm{CV}^{\mathrm{c}}$ & 27.1 & 23.0 & 44.8 & 25.7 \\
\hline
\end{tabular}

\footnotetext{
${ }^{a}$ Range is given in brackets. ${ }^{b}$ Not determined. ${ }^{c}$ Coefficient of variation.
}

considered to be similar and given the same name by the farmers were found to be genetically distinct. This is the case for the "varieties" doniyoka a and b, chamwoka a and b, sakarabokuru $a$ and $b$, zogua a and b, tokogbessenou a and b, mare dobi a and b, yinan a and b, yowinka a and b, sotakaman a and b, and mahi a and b. Farmers use various criteria to identify their crops. The adaptation of a variety to particular agroecological conditions, its morphological aspects, and the taste of its products are key factors affecting crop identification by farmers, rather than purely genetic criteria. This leads to naming that is meaningful and significant. All varieties that meet the same criteria may get the same name, even though they may be genetically distinct. In some cases, the AFLP-based distinction agrees well with the farmers' assignment on the basis of similarity between varieties, as some varieties that are given the same name by farmers are also found to be similar by the AFLP analysis (for example, chamwoka a and c, talemoula a and $b$, and natisoya a and b). When similar farmers' varieties in clusters are examined, it appears in most cases that varieties in a specific cluster were obtained from the same region. All similar farmers' varieties in cluster 1 (except varieties chamwoka and tamabano) and in clusters 2, 6, and 8 are from Banikoara. Varieties in clusters 4,5 , and 10 are from Toucountouna, and those in clusters 3, 7, and 11 originated from Djougou. This regional resemblance in farmers' varieties may be explained as follows. First, it is plausible that during the seed collection in 
Table 2. Analysis of Variance for the Effect of Locality on Fe, Zn, and Phytate (IP6)

\begin{tabular}{|c|c|c|c|c|c|c|}
\hline \multirow[b]{2}{*}{ genotype } & \multirow[b]{2}{*}{ region } & \multirow[b]{2}{*}{ village } & \multirow[b]{2}{*}{$\mathrm{DF}^{b}$} & \multicolumn{3}{|c|}{ Fvalue $^{a}$} \\
\hline & & & & $\mathrm{Fe}$ & $\mathrm{Zn}$ & IP6 \\
\hline 1 & Banikoara, Toucountouna & Kokey, Gounbakou, Donparou, Tampégré & 9 & $14^{* *}$ & $4^{*}$ & $8.3^{* \star}$ \\
\hline 2 & Banikoara & Gounbakou, Kokey & 5 & $47.6^{\star *}$ & $15.3^{*}$ & $3.5^{*}$ \\
\hline 3 & Djougou & Bareï, Banénou, Onklu & 4 & $9.2^{*}$ & $9.4^{*}$ & $5.2^{*}$ \\
\hline 4 & Toucountouna & Tampatou, Tchaklakou, Tampégré & 3 & $30.5^{*}$ & $243.9^{* *}$ & $22.3^{* *}$ \\
\hline 5 & Toucountouna & Toucountouna & 2 & $0.1 \mathrm{~ns}$ & $14.1^{*}$ & $4.6 \mathrm{~ns}$ \\
\hline 6 & Banikoara & Kokey, Donparou & 2 & $9.2 n s$ & $0.06 \mathrm{~ns}$ & $10.6^{*}$ \\
\hline 7 & Djougou & Bareï, Partogo & 2 & $13.4^{*}$ & $16.9^{*}$ & $1.1 \mathrm{~ns}$ \\
\hline
\end{tabular}

${ }^{a *}, F$ significant at the 0.05 level; ${ }^{* *}, F$ significant at the 0.01 level; ns, not significant. ${ }^{b}$ Degrees of freedom.

a specific region, farmers mixed the varieties up, attributing different names to the same varieties. The second possible reason is linked to seed exchange between farmers and villages. In the adopting community the name of the traded farmers' variety often changed, taking either the name of the farmer who introduced it or the name of the village it came from.

$\mathrm{Fe}$ and $\mathrm{Zn}$ Concentrations of Grains. The $\mathrm{Fe}$ and $\mathrm{Zn}$ concentrations of the different farmers' sorghum varieties are presented in Table $\mathbf{1}$. The 45 sorghum genotype clusters vary significantly $(P<0.01)$ in their Fe and $\mathrm{Zn}$ concentrations. The Fe concentration ranged from 31.5 to $99.0 \mathrm{mg} / \mathrm{kg}$ with an average value of $58.8 \mathrm{mg} / \mathrm{kg}$. Values for $\mathrm{Zn}$ ranged from 14.0 to 38.0 with an average of $24.4 \mathrm{mg} / \mathrm{kg}$. In most genotypes the level of grain-Fe is higher than that of $\mathrm{Zn}$, the difference being $1-5$-fold. The level of Fe found in the present germplasm is in agreement with values reported in the literature. Jambunathan (35) reported an average Fe concentration of $59 \mathrm{mg} / \mathrm{kg}$ with a range of $26-96 \mathrm{mg} / \mathrm{kg}$ in samples of $\sim 100$ varieties of sorghum.

Within the genotype clusters, samples grown in various locations show significantly different $\mathrm{Fe}$ and $\mathrm{Zn}$ levels, suggesting effects of the environment. The analysis of variance for the effect of locality on $\mathrm{Fe}, \mathrm{Zn}$, and phytate revealed a significant impact of the cultivation locations on the mineral concentrationof the grain (Table 2). The variation observed in grain-Fe and $-\mathrm{Zn}$ could not be explained by the observed genetic variation as the analysis of molecular variance failed to detect any significant correlation between the genetic distance of the varieties and grain-Fe and $-\mathrm{Zn}$ concentrations. Any genetic differences, if present, might have been masked by larger environmental differences. Even though the farmers' varieties were grown in the same agroecological zone on tropical ferruginous soils classified as Ferric lixisol by FAO (36), the soil fertility and microclimate may vary between regions/villages and induce differences in mineral accumulation by the plant (37). Banzinger and Long (16) found highly significant effects of "environment" and "genotype $\times$ environment" interaction on grain-Fe and $-\mathrm{Zn}$ concentrations among maize germplasm in Zimbabwe and Mexico. Further studies are needed to determine the contribution of different factors, that is genotype $(\mathrm{G})$, environment $(\mathrm{E})$, and $\mathrm{G} \times \mathrm{E}$ to the total grain-Fe and $-\mathrm{Zn}$ variation.

The $1000 \mathrm{kw}$ also varies significantly $(P<0.01)$ among farmers' varieties and is inversely correlated with the grain-Fe: the larger the grain, the lower its Fe concentration (Table 3). In maize, Banzinger and Long (16) also reported the grain-Fe concentration to correlate inversely with grain size, corroborating the present finding. The authors ascribed this to the effect of dilution caused by enhanced grain-starch content. In wheat, there was no relationship between seed size and micronutrient density, probably because of the small amounts of microelements involved (17).

Farmers' varieties of perceived high and poor food quality showed no significant difference in terms of $\mathrm{Fe}$ and $\mathrm{Zn}$
Table 3. Pearson Correlation Matrix between Iron, Zinc, Phytate (IP6), Ash, and $1000 \mathrm{kw}$ of Sorghum Grains ${ }^{a}$

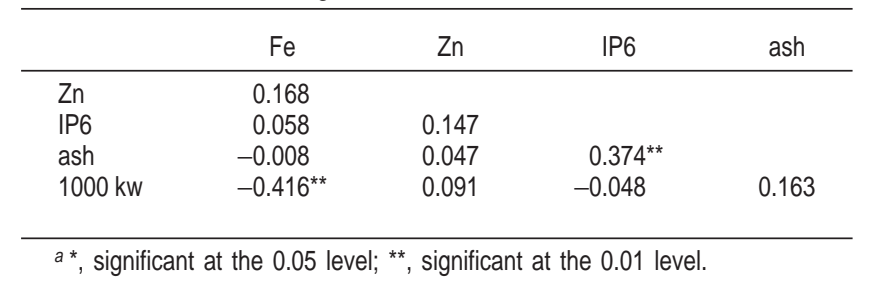

Table 4. Concentrations of Fe, Zn, and Phytate (IP6) of Farmers' Varieties of Sorghum Grouped by Agromorphological Traits

\begin{tabular}{lllc}
\hline \multicolumn{1}{c}{ trait } & $\mathrm{Fe}(\mathrm{mg} / \mathrm{kg})$ & $\mathrm{Zn}(\mathrm{mg} / \mathrm{kg})$ & IP6 $(\%)$ \\
\hline maturity & & & \\
$\quad$ late $(n=32)$ & $67.0 \pm 18.4 \mathrm{a}^{\mathrm{a}}$ & $29.0 \pm 5.3 \mathrm{a}$ & $1.14 \pm 0.43 \mathrm{a}$ \\
$\quad$ early $(n=20)$ & $68.0 \pm 17.0 \mathrm{a}$ & $27.1 \pm 6.6 \mathrm{a}$ & $1.41 \pm 0.77 \mathrm{a}$ \\
$\quad$ intermediate $(n=8)$ & $59.6 \pm 14.1 \mathrm{a}$ & $30.6 \pm 8.6 \mathrm{a}$ & $1.30 \pm 0.50 \mathrm{a}$ \\
color & & & \\
$\quad$ red $(n=11)$ & $70.0 \pm 20.1 \mathrm{a}$ & $29.6 \pm 9.0 \mathrm{a}$ & $1.45 \pm 0.72 \mathrm{a}$ \\
$\quad$ white $(n=29)$ & $64.9 \pm 19.3 \mathrm{a}$ & $28.9 \pm 5.6 \mathrm{a}$ & $1.12 \pm 0.40 \mathrm{a}$ \\
pink $(n=25)$ & $65.0 \pm 14.5 \mathrm{a}$ & $28.1 \pm 5.7 \mathrm{a}$ & $1.32 \pm 0.62 \mathrm{a}$ \\
yellow $(n=5)$ & $65.8 \pm 15.0 \mathrm{a}$ & $28.0 \pm 4.5 \mathrm{a}$ & $0.87 \pm 0.25 \mathrm{a}$ \\
1000 kw & & & \\
large $(n=9)$ & $57.7 \pm 12.4 \mathrm{a}$ & $26.0 \pm 3.3 \mathrm{a}$ & $0.95 \pm 0.43 \mathrm{a}$ \\
medium $(n=24)$ & $63.3 \pm 15.7 \mathrm{ab}$ & $30.8 \pm 7.2 \mathrm{a}$ & $1.42 \pm 0.72 \mathrm{~b}$ \\
small $(n=25)$ & $71.6 \pm 19.0 \mathrm{~b}$ & $27.5 \pm 6.1 \mathrm{a}$ & $1.12 \pm 0.42 \mathrm{ab}$ \\
& & &
\end{tabular}

${ }^{a}$ Means \pm standard deviation. Means with the same letter are not significantly different according to the LSD at the 0.05 level. ${ }^{b}$ One thousand kernel weight: large $=1000 \mathrm{kw}>40$, medium $=30<1000 \mathrm{kw}<40$, small $=1000 \mathrm{kw}<30$.

concentrations. Likewise, the crop duration (late, intermediate, early) and the seed color (red, white, pink, yellow) showed no significant relationship with the grain-Fe and $-\mathrm{Zn}$ contents (Table 4). Implications of these findings for breeding are that selection for Fe or $\mathrm{Zn}$ does not automatically mean selection for good food quality properties and/or a certain plant maturity or seed color. Farmers' varieties are products of genetic makeup and cultivation conditions. To enable the establishment of a germplasm collection for high $\mathrm{Fe}$ and $\mathrm{Zn}$ concentrations, further experimentation will be required to eliminate effects of cultivation conditions. A collection with sufficient variability of mineral levels would allow selection for other important traits, such as good food quality, seed color, and crop duration.

Phytate Content and Fe and Zn Availability. The phytate concentration of the grain varied significantly $(P<0.01)$ among varieties (Table 1). Values ranged from 0.45 to $3.53 \%$ with a mean value of $1.2 \%$. The highest phytate levels were found in the farmers' varieties sodaya $(3.53 \%)$, hannitchre $(2.22 \%)$, and sopoya $(2.06 \%)$. Interestingly, these three varieties do not belong to the varieties that are highly preferred by farmers for foods. The phytate values found for these three farmers' varieties are higher than those earlier reported for sorghum. Frossard et al. 


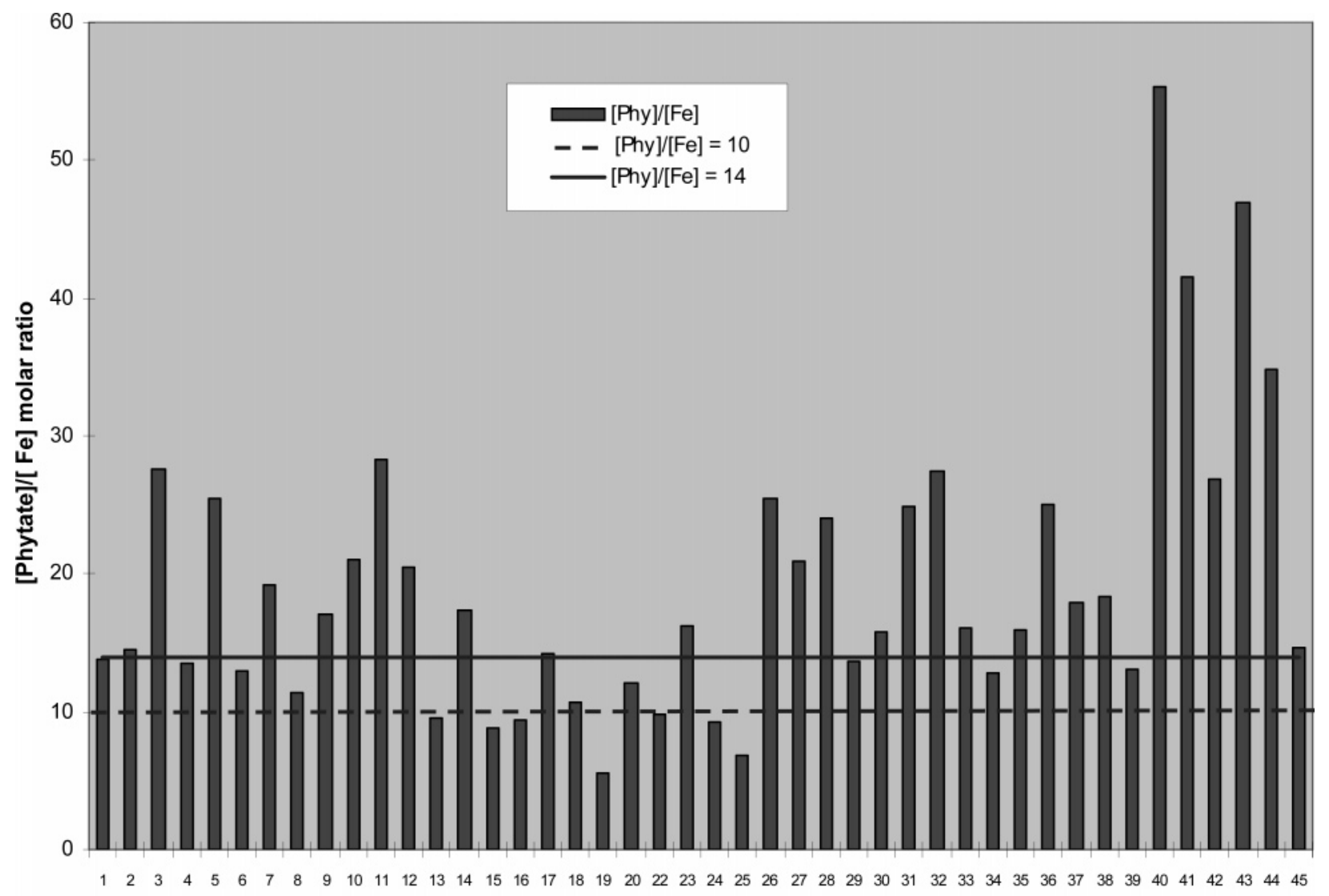

genotype

Figure 1. Sorghum varieties with [phytate]/[Fe] molar ratio and indication of range 10-14.

(15) reported phytate values ranging from 0.9 to $1.35 \%$ in sorghum, whereas Doherty et al. (38) reported values between 0.26 and $0.4 \%$ in 24 Indian sorghum varieties. The majority $(56 \%)$ of the farmers' varieties (Table 1) have a phytate concentration of $>1.0 \%$. Farmers' varieties with a phytate concentration of $<0.5 \%$ account only for $4 \%$. The grain-phytate correlated with the ash content of the grain (Table 3), which could be expected as elements such as phosphorus, iron, and other minerals that account for the ash are also part of the phytate and phytate-mineral complex structure $(39,40)$. The fact that the phytate concentrations of the grain vary significantly across villages (Table 2) and significantly correlate with the genetic structure among the varieties (data not shown) suggests that the grain-phytate concentration is environmentally, as well as genetically, determined.

We grouped the farmers' varieties according to their food quality traits as appreciated by farmers on a three-step scale, that is, high, medium, and low (23), and calculated the [phytate]/ $[\mathrm{Fe}]$ and [phytate]/[Zn] molar ratios as an index for the potential mineral bioavailability (Table 5); that is, other food-processing beneficial effects were not taken into account. All varieties in each food quality group had [phytate]/[Zn] molar ratios $>15$, which suggests that $\mathrm{Zn}$ availability from the present varieties is very low and requires substantial improvement either by breeding, agronomy, or food processing. On the other hand, the average [phytate]/[Fe] molar ratios in the food groups ranged between 5 and 56 . Therefore, farmers' varieties with a potentially adequate $\mathrm{Fe}$ availability are expected within the present germplasm. To identify varieties with adequate Fe availability, we determined the [phytate]/[Fe] molar ratio for each variety. Of the 45 farmers' varieties analyzed, 15\% had [phytate]/[Fe] molar ratios below 10 . Those with [phytate]/[Fe] molar ratios
Table 5. [Phytate]/[Fe] and [Phytate]/[Zn] Molar Ratios of Farmers' Varieties of Sorghum Grouped by Food Quality

\begin{tabular}{|c|c|c|c|}
\hline food & $\begin{array}{l}\text { varieties with } \\
\text { quality } \\
\text { perceived as }\end{array}$ & {$[$ phytate $]\left[[\mathrm{Fe}]^{a}\right.$} & {$[$ phytate $][Z \mathrm{Zn}]^{b}$} \\
\hline dibou & $\begin{array}{l}\text { high }(n=33) \\
\text { medium }(n=18) \\
\text { low }(n=9)\end{array}$ & $\begin{array}{c}20.2 \pm 10.1 \\
{[5.0-56.3]^{c}} \\
23.2 \pm 4.7 \\
{[7.0-47.0]} \\
12.7 \pm 4.7 \\
{[5.6-20.3]}\end{array}$ & $\begin{array}{c}51.6 \pm 23.1 \\
{[22.3-127.6]} \\
58.5 \pm 30.4 \\
{[18.7-124.9]} \\
43.3 \pm 24.0 \\
{[17.2-100.3]}\end{array}$ \\
\hline sorou & $\begin{array}{l}\text { high }(n=32) \\
\text { medium }(n=17) \\
\text { low }(n=11)\end{array}$ & $\begin{array}{c}20.8 \pm 9.9 \\
{[7.8-56.3]} \\
20.6 \pm 11.3 \\
{[5.0-47.0]} \\
17.0 \pm 9.3 \\
{[6.8-41.5]}\end{array}$ & $\begin{array}{c}52.3 \pm 22.5 \\
{[24.5-127.6]} \\
54.8 \pm 29.0 \\
{[22.1-115.8]} \\
45.6 \pm 28.3 \\
{[17.1-124.9]}\end{array}$ \\
\hline tchoukoutou & $\begin{array}{l}\text { high }(n=16) \\
\text { medium }(n=19) \\
\text { low }(n=25)\end{array}$ & $\begin{array}{l}21.3 \pm 9.6 \\
{[9.3-47.0]} \\
17.5 \pm 8.8 \\
{[5.0-35]} \\
20.1 \pm 11.1 \\
{[6.8-56.3]}\end{array}$ & $\begin{array}{c}57.2 \pm 25.8 \\
{[18.7-115.8]} \\
44.8 \pm 19.5 \\
{[22.1-87.3]} \\
51.2 \pm 29.0 \\
{[17.1-127.6]}\end{array}$ \\
\hline
\end{tabular}

a Phytate/Fe molar ratio $=(\mathrm{mg}$ of IP6/molecular weight of IP6)/(mg of Fe/ molecular weight of $\mathrm{Fe}) .{ }^{b}$ Phytate/Zn molar ratio $=(\mathrm{mg}$ of IP6/molecular weight of IP6)/(mg of $\mathrm{Zn} / \mathrm{molecular}$ weight of $\mathrm{Zn}) .{ }^{c}$ Range given in brackets.

between 10 and 14 accounted for $20 \%$ (Figure 1). The varieties with [phytate]/[Fe] below 14 are unevenly distributed among the regions investigated. Most of them are located in Banikoara (25\%) followed by Toucountouna (7\%). Only one of these varieties originates from Djougou. Environmental effects (e.g., soil composition) may be a major contributing factor to the 
uneven distribution. Interestingly, among these promising farmers' varieties for Fe availability, some-that is, tokogbessenou, mahi swan, biodahu, saï maï, mare dobi, chabicouman, and sakarabokuru-are regarded as having a high food quality by farmers (23). This group of top varieties in terms of Fe availability is recommended for the preparation of a food product such as dibou, for which the preparation technology mainly involves cooking, an operation that has only a minor diminishing effect on phytate. The top varieties could also be of interest to breeders as a basis for seed selection for high mineral availability. Further research would then be required to test these varieties under controlled conditions to assess the genetic impact on [phytate]/[Fe] molar ratios.

In conclusion, the AFLP technique allowed us to cluster the 76 collected farmers' varieties into 45 distinct genotypes. The grain-Fe and -Zn concentrations of the grains varied significantly among farmers' varieties, but this variation could not be related to genetic variance. Only the cultivation location affected the mineral concentration. Further studies are needed to assess the impact of genotype and environmental conditions on the grainFe and $-\mathrm{Zn}$ levels. The phytate concentration of the grain is governed by the growing environment, as well as the genetic makeup of the varieties, as revealed by the analysis of molecular variance. Within the farmers' germplasm we detected seven varieties with adequate $\mathrm{Fe}$ supply in food uses. Farmers' varieties with high [phytate]/[Fe] and [phytate]/[Zn] molar ratios may still be suitable to deliver Fe and $\mathrm{Zn}$ to consumers, provided that they are processed adequately. For instance, unit operations such as soaking, germination, and fermentation have been reported to induce a significant reduction of antinutritional factors and to improve the nutritional quality of cereals-based foods $(8,41-43)$. Therefore, improved mineral availability could be expected from grains processed with such local methods. In further studies, attention will be focused on the impact of food-processing operations during the preparation of common sorghum-based foods of Benin.

\section{ACKNOWLEDGMENT}

We gratefully acknowledge Dr. Rene Smulders (Plant Research International, Wageningen, The Netherlands), Jeroen Werij, Linda Kodde, and Dirk Visser for AFLP analysis, and Diaan Jamar for HPLC assistance.

\section{LITERATURE CITED}

(1) Gibson, R. S. Zinc nutrition in developing countries. Nutr. Res. Rev. 1994, 7, 151-173.

(2) Dossa, R. A. M.; Ategbo, E. A. D.; de Koning, F. I. H. A.; van Raaij, J. M. A.; Hautvast, J. G. A. J. Impact of iron supplementation and deworming on growth performance in preschool Beninese children. Eur. J. Clin. Nutr. 2001, 55, 223-228.

(3) Oikeh, S. O.; Menkir, A.; Maziya-Dixon, B.; Welch, R.; Glahn, R. P. Assessment of concentrations of iron and zinc and bioavailable iron in grain of early-maturing tropical maize varieties. J. Agric. Food Chem. 2003, 51, 3688-3694.

(4) Duodu, K. G.; Taylor, J. R. N.; Belton, P. S.; Hamaker, B. R. Factors affecting sorghum protein digestibility. J. Cereal Sci. 2003, 38, 117-131.

(5) Kayodé, A. P. P.; Adégbidi, A.; Linnemann, A. R.; Nout, M. J. R.; Hounhouigan, D. J. Quality of farmers' varieties of sorghum and derived foods as perceived by consumers in Benin. Ecol. Food Nutr. 2005, 44, 271-294.

(6) Office Nationale d'Appui à la Sécurité Alimentaire: Evaluation de la campagne agricole 2000/2001 et les pespectives alimentaires pour 2001 au Bénin; Rapport général; Cotonou, Bénin, 2001; Vol. 1, 41 pp.
(7) Diawara, B.; Kaboré, I. Z.; Sawadogo, L. Essai de stockage en vrac du sorgho rouge et niébé: amélioration des structures de stockage traditionnelles. In Processing and Industrial Utilisation of Sorghum and Related Cereals in Africa; Menyonga, J. M., Bezuneh, T., Nwassike, C. C., Sedego, P. M., Tenkouano, E., Eds.; OAU/STRC-SAFGRAD Regional Symposium; Agence Internationale de Communication pour le Développement: Ouagadougou, Burkina-Faso, 1995; pp 207-214.

(8) Svanberg, U.; Lorri, W. Fermentation and nutrient availability. Food Control 1997, 8, 319-327.

(9) Graf, E. Chemistry and application of phytic acid: an overview. In Phytic Acid: Chemistry and Application; Graf, E., Ed.; Pilatus Press: Minneapolis, MN, 1986; pp 1-21.

(10) Hulse, J. H.; Laing, E. M.; Pearson, D. E. Sorghum and the Millets: Their Composition and Nutritive Value; Academic Press: London, U.K., 1980.

(11) Saha, P. R.; Weaver, C. M.; Mason, A. C. Mineral bioavailability in rats from intrinsically labeled whole wheat flour of various phytate levels. J. Agric. Food Chem. 1994, 42, 2531-2535.

(12) Davies, N. T.; Olpin, S. Studies on the phytate:zinc molar content in diet as a determinant of $\mathrm{Zn}$ availability to young rats. $\mathrm{Br}$. J. Nutr. 1979, 41, 591-603.

(13) Turnlund, J. R.; King, J. C.; Keyes, W. R.; Gong, B.; Michel, M. C. A stable isotope study of zinc absorption in young men: effect of phytate and $\alpha$-cellulose Am. J. Clin. Nutr. 1984, 40, 1071-1077.

(14) Oberleas, D.; Harland, B. F. Phytate content of foods: effect on dietary Zn bioavailability. J. Am. Diet. Assoc. 1981, 79, 433436.

(15) Frossard, E.; Bucher, M.; Mächler, F.; Mozafar, A.; Hurrell, R. Potential for increasing the content and bioavailability of $\mathrm{Fe}$, $\mathrm{Zn}$, and $\mathrm{Ca}$ in plants for human nutrition. J. Sci. Food Agric. 2000, 80, 861-879.

(16) Banzinger, M.; Long, J. The potential for increasing the iron and zinc density of maize through plant breeding. Food Nutr. Bull. 2000, 21, 397-400.

(17) Graham, R.; Senadhira, D.; Beebe, S.; Iglesias, C.; Monasterio, I. Breeding for micronutrient density in edible portion of staple food crops: conventional approaches. Field Crops Res. 1999, $60,57-80$.

(18) Shumba, D. Promotion of a small grains seed production by a nongovernmental organization in Zimbabwe. In Drought-Tolerant Crops for Southern Africa: Proceedings of the SADC/ ICRISAT Regional Sorghum and Millet Quality Workshop; Leuschner, L., Manthe, C. S., Eds.; International Crops Research Institute for the Semi-Arid Tropics: Patancheru, India, 1994; pp 227-234.

(19) Murty, D. S.; Kumar, K. A. Traditional uses of sorghum and millet. In Sorghum and Millets: Chemistry and Technology; Dendy, D. A. V., Ed.; American Association of Cereal Chemists: St. Paul, MN, 1995; pp 185-221.

(20) Nkongolo, K. K.; Nsapato, L. Genetic diversity in Sorghum bicolor (L.) Moench accessions from different ecogeographical regions in Malawi assessed with RAPDs. Genet. Resour. Crop Evol. 2003, 50, 149-156.

(21) Uptmoor, R.; Wenzel, W.; Friedt, W.; Donaldson, G.; Ayisi, K.; Ordon, F. Comparative analysis on the genetic relatedness of Sorghum bicolor accessions from southern Africa by RAPDs, AFLPs and SSRs. Theor. Appl. Genet. 2003, 106, 1316-1325.

(22) Vos, P.; Hogers, R.; Bleeker, M.; Reijans, M.; Van der Lee, T.; Hornes, M.; Frijters, A.; Pot, J.; Peleman, J.; Kuiper, M.; Zabeau, M. AFLP: a new technique for DNA fingerprinting. Nucleic Acids Res. 1995, 23, 4407-4414.

(23) Kayodé, A. P. P.; Linnemann, A. R.; Nout, M. J. R.; Hounhouigan, D. J.; Stomph, T. J.; Smulders, M. J. M. Diversity and food quality properties of farmers' varieties of sorghum from Bénin. J. Sci. Food Agric. 2005, in press.

(24) Saïdou, A.; Kuyper, T. W.; Kossou, D. K.; Tossou, R.; Richard, $\mathrm{P}$. The sustainable soil fertility management in Benin: learning from farmers. NJAS-Wageningen J. Life Sci. 2004, 52, 349368. 
(25) Faure, P. Notice explicative 66, carte pédologique de reconnaissance de la République Populaire du Bénin à 1/200.000, Feuille de Natitingou (6)-Porga (8); Travaux et documents de l'ORSTOM: Paris, France, 1977; 68 pp.

(26) Fulton, E.; Chunwongse, J.; Tanksley, S. D. Microprep protocol for extraction of DNA from tomato and other herbaceous plants. Plant Mol. Biol. Rep. 1995, 13, 207-209.

(27) Myburg, A. A.; Remington, D. L.; O’Malley, D. M.; Sederoff, R. R.; Whetten, R. W. High-throughput AFLP analysis using infrared dye-labeled primers and an automated DNA sequencer. Biotechniques 2001 30, 348-357.

(28) Temminghof, E. Soil and Plant Analysis. Part 3. Plant Analysis Procedures; Wageningen University Environmental Sciences: Wageningen, The Netherlands, 2000.

(29) Nei, M.; Li, W.-H. Mathematical model for studying genetic variation in terms of restriction endonucleases. Proc. Natl. Acad. Sci. U.S.A. 1979, 76, 5269-5273.

(30) Excoffier, L.; Smouse, P. E.; Quattro, J. M. Analysis of molecular variance inferred from metric distances among DNA haplotypes: application to human mitochondrial DNA restriction data. Genetics 1995, 131, 479-491.

(31) Cheng, Z.; Lu, B.; Sameshima K.; Fu, D.; Chen, J. Identification and genetic relationships of Kenef (Hibiscus cannabinus L.) germplasm revealed by AFLP analysis. Genet. Resour. Crop Evol. 2004, 51, 393-401.

(32) Maciel, F. L.; Echeverrigaray, S.; Gerald, L. T. S.; Grazziotin, F. G. Genetic relationships and diversity among Brazilian cultivars and landraces of common beans (Phaseolus vulgaris L.) revealed by AFLP markers. Genet. Resour. Crop Evol. 2003, 50, 887-893.

(33) Schut, J. W.; Qi, X.; Stam, P. Association between relationship measures based on AFLP markers, pedigree data and morphplogical traits in barley. Theor. Appl. Genet. 1997, 95, 11611168.

(34) Cervera, M. T.; Cabezas, J. A.; Sancha J. C.; Martinez de Toda, F.; Martinez-Zapater J. M. Application of AFLPs to the characterization of grapevine Vitis vinifera L. genetic resources. A case study with accessions from Rioja (Spain). Theor. Appl. Genet. 1998, 97, 51-58.

(35) Jambunathan, R. Improvement of the nutritional quality of sorghum and pearl millet. Food Nutr. Bull. 1980, 2, 11-16.
(36) Anonymous. FAO-UNESCO Soil Map of the World, revised legend; Soils Bulletin 60; FAO: Rome, Italy, 1990; 119 pp.

(37) Graham, R. D.; Welch, R. M. Breeding for Staple Food Crops with High Micronutrient Density; Working Paper on Agriculture Strategies for Micronutrients 3; International Food Policy Research Institute: Washington, DC, 1996; p 80.

(38) Doherty, C.; Faubion, J. M.; Rooney, L. W. Semiautomated determination of phytate in sorghum and sorghum products. Cereal Chem. 1982, 59, 373-377.

(39) Raboy, V. The biochemistry and genetics of phytic acid synthesis. In Inositol Metabolism in Plants; Morré, D., Boss, W., Loewus, F., Eds.; Wiley-Liss: New York, 1990; pp 55-76.

(40) Pernolley, J.; Protein bodies of seeds: ultrastructure biochemistry, biosynthesis and degradation. Phytochemistry 1978, 17, 14731480.

(41) Traoré, T.; Mouquet, C.; Icard-Vernière, C.; Traoré, A. S.; Trèche, S. Changes in nutrient composition, phytate and cyanide contents and $\alpha$-amylase activity during cereal malting in small production units in Ouagadougou (Burkina Faso). Food Chem. 2004, $88,105-114$.

(42) Obizoba, I. C.; Atii, J. V. Effect of soaking, sprouting, fermentation and cooking on nutrient composition and some antinutritional factors of sorghum (Guinesia) seeds. Plant Foods Hum. Nutr. 1991, 41, 203-212.

(43) Subramanian, V.; Murty, D. S.; Rao, N. S.; Jambunathan, R. Chemical changes and diastatic activity in grains of sorghum (Sorghum bicolor) cultivars during germination. J. Sci. Food Agric. 1992, 58, 35-41.

Received for review August 31, 2005. Revised manuscript received November 4, 2005. Accepted November 7, 2005. Financial support provided by Wageningen University through the North-South Interdisciplinary Research and Education Fund (INREF) is gratefully acknowledged. The International Foundation for Science, Stockholm, Sweden is acknowledged for financial support to A.P.P.K. (Grant IFS E/3736-1).

JF0521404 